185. LC

Draft

Published in Oxford Journal of Law and Religion 1 (2012): 151-168

\title{
Church, State, and Marriage: Four Early Modern Protestant Models
}

\author{
John Witte, Jr. ${ }^{1}$
}

\begin{abstract}
This Article analyzes four early modern Protestant models of marriage that emerged in place of the medieval Catholic sacramental model. These are the Lutheran social model of marriage in Germany and Scandinavia, the Calvinist covenantal model in Geneva, France, the Netherlands, and Scotland, the Anglican commonwealth model in England and its colonies, and the budding separationist model of marriage developed by John Locke. Theologically, the differences between these models can be traced to medieval Catholic sacramental theology, Lutheran two kingdoms doctrines, Calvinist covenantal constructions, Anglican commonwealth theory, and Lockean contractarian theories, respectively. Politically, these differences can be seen in shifts in marital jurisdiction: Medieval Catholics vested exclusive marital jurisdiction in the church. Anglicans left marital jurisdiction to church courts, subject to royal oversight and Parliamentary legislation. Calvinists assigned interlocking marital roles to local consistories and city councils. Lutherans consigned primary marital jurisdiction to the territorial prince or urban council. Locke pressed for a sharper separation of church and state in the governance of marriage. The Article concludes with a brief reflection of the implications of these early modern teachings, especially Locke's, for modern contests over church, state, and family.

Keywords: Martin Luther; John Calvin; Henry VIII; John Locke; Roman Catholicism; Lutheranism; Calvinism; Anglicanism; Enlightenment; marriage; family law; religious liberty; church-state relations; marital pluralism

\footnotetext{
${ }^{1}$ For detailed sources covered in this summary article, see my volumes, From Sacrament to Contract: Marriage, Religion, and Law in the Western Tradition, 2d enl. ed. (Louisville, KY: Westminster John Knox Press, 2012), chaps. 3-8; Law and Protestantism: The Legal Teachings of the Lutheran Reformation (Cambridge: Cambridge University Press, 2002), 177-256; Sex, Marriage and Family in John Calvin's Geneva, 2 vols. (Grand Rapids, Mich.: Wm. B. Eerdmans Publishing Co., 2005, 2012 ) (with Robert M. Kingdon); To Have and to Hold: Marrying and its Documentation in Western Christendom, 400-1600 (Cambridge: Cambridge University Press, 2007) (with Philip L. Reynolds); and The Reformation of Rights: Law, Religion, and Human Rights in Early Modern Calvinism (Cambridge: Cambridge University Press, 2007), 209-276.
} 


\section{Introduction}

Marriage was one of the hotly contested issues of the sixteenth-century Protestant Reformation and one of the first institutions to be reformed. The leading Protestant theologians - Martin Luther and Philip Melanchthon, Thomas Cranmer and William Tyndale, Martin Bucer and John Calvin - all prepared lengthy tracts on the subject in their first years of reform. Scores of leading jurists took up legal questions of marriage in their consilia and commentaries, often working under the direct inspiration of Protestant theology and theologians. Virtually every city and territory on the Continent that converted to the Protestant cause in the first half of the sixteenth century had new marriage laws on the books within a decade after accepting the Reformation.

The Protestant reformers' early preoccupation with marriage was partly driven by their theology. Many of the core issues of the Reformation were implicated by the prevailing Catholic sacramental theology and canon law of marriage. The medieval Catholic Church's jurisdiction over marriage was, for the reformers, a particularly flagrant example of the church's usurpation of the state's authority. The Catholic sacramental concept of marriage, on which the church predicated its jurisdiction, was for the reformers a self-serving theological fiction. The canonical prohibition on the marriage of clergy and monastics stood sharply juxtaposed to Protestant doctrines of sexual sin and the Christian vocation. The canon law's long roll of impediments to betrothal and marriage, its prohibitions against complete divorce and remarriage, and its close regulations of sexuality, parenting, and education all stood in considerable tension with the reformers' understanding of the Bible. That a child could enter marriage without parental permission or church consecration betrayed, in the reformers' views, basic responsibilities of family, church, and state to children. Issues of marriage doctrine and law thus implicated and epitomized many of the cardinal theological issues of the Protestant Reformation.

The reformers' early preoccupation with marriage was also partly driven by their politics. A number of early leaders of the Reformation faced aggressive prosecution by the Catholic Church and its political allies for violation of the canon law of marriage and celibacy. Among the earliest Protestant leaders were ex-priests and ex-monastics who had forsaken their orders and vows, and married shortly thereafter. Indeed, one of the acts of solidarity with the new Protestant cause was to marry or divorce in open violation of the canon law and in defiance of a bishop's instructions. The most (in)famous example was the marriage of ex-monk Martin Luther with the ex-nun Katherine von Bora - an iconic act of marital freedom for Protestants, a flagrant crime of double spiritual incest for Catholics. As Catholic Church authorities began to prosecute these canon law offences, Protestant theologians and jurists rose to the defense of their co-religionists, producing a welter of briefs, letters, sermons, and pamphlets that denounced traditional norms and 
pronounced a new theology of marriage that was quickly translated into new legal terms.

This Article analyzes the three main theological and legal models of church, state, and marriage produced, in response to prevailing Catholic norms, during the Lutheran, Calvinist, and Anglican Reformations. It then shows how, a century later, the English philosopher, John Locke, sought to harmonize these oft-competing perspectives through a new commonwealth model of marriage.

\section{Medieval Catholic Background}

From the twelfth to the sixteenth centuries, marriage was principally subject to the theology and law of the Catholic Church. ${ }^{2}$ The medieval church treated marriage and the family in a threefold manner -- at once as a natural, contractual, and sacramental unit. First, marriage was a natural association, created by God to enable man and woman to "be fruitful and multiply" (Gen. 1:28) and to raise children in the service and love of God. Since the fall into sin, marriage had also become a remedy for lust, a channel to direct one's natural passion to the service of the community and the church. Second, marriage was a contractual unit, formed in its essence by the mutual consent of the parties. This contract prescribed for couples a life-long relation of love, service, and devotion to each other and proscribed unwarranted breach or relaxation of their connubial and parental duties. Third, marriage, when properly contracted between Christians, rose to the dignity of a sacrament. The temporal union of body, soul, and mind within the marital estate symbolized the eternal union between Christ and his church, and brought sanctifying grace to the couple, their children, and the church. This sacramental perspective helped to integrate the natural and the contractual dimensions of marriage and to render marriage a central concern of the church and its canon law.

Though a sacrament and a sound way of Christian living, however, marriage was not considered to be particularly spiritually edifying. The medieval church regarded marriage more as a remedy for sin than a recipe for righteousness. Marital life was considered less commendable than celibate life, propagation less virtuous than contemplation. Clerics and monastics were thus to forgo marriage as a condition for ecclesiastical service. Those who could not forgo marriage were not worthy of the church's holy orders and offices. Celibacy was something of a litmus test of spiritual discipline and social superiority.

\footnotetext{
${ }^{2}$ For good overviews, see James A. Brundage, Law, Sex, and Christian Society in Medieval Europe (Chicago: University of Chicago Press, 1987); Charles Donahue, Law, Marriage and Society in the Later Middle Ages (Cambridge: Cambridge University Press, 2007); R.H. Helmholz, Marriage Litigation in Medieval England (Cambridge: Cambridge University Press, 1974); Theodore Mackin, S.J., Marriage in the Catholic Church, 2 vols. (New York: Paulist Press, 1984-1989); Philip L. Reynolds, Marriage in the Western Church: The Christianization of Marriage During the Patristic and Early Modern Periods (Leiden: E.J. Brill, 1994).
} 
From the twelfth century forward, the Catholic Church built upon this conceptual foundation a comprehensive canon law of marriage that was enforced by church courts throughout much of Western Christendom. From the twelfth to the sixteenth centuries, the church's canon law of marriage was the principal marriage law of the West. A civil law or a common law of marriage, where it existed, was generally considered supplemental and subordinate. Consistent with the naturalist perspective on marriage, the canon law punished contraception and abortion as violations of the created marital functions of propagation and childrearing. It proscribed unnatural relations, such as incest and polygamy, and unnatural acts such as bestiality, buggery, and sodomy. Consistent with the contractual perspective, the canon law ensured voluntary unions by dissolving marriages formed through mistake, duress, fraud, or coercion, and granting husband and wife alike equal rights to enforce conjugal debts that had been voluntarily assumed. Consistent with the sacramental perspective, the church protected the sanctity and sanctifying purpose of marriage by declaring valid marital bonds to be indissoluble, and by dissolving invalid unions between Christians and non-Christians or between parties related by various legal, spiritual, blood, or familial ties. This canon law of marriage, grounded in a rich sacramental theology and ecclesiastical jurisprudence, was formalized and systematized by the Council of Trent in the Decree Tametsi of 1563.

\section{Three Sixteenth-Century Reformation Models}

The Lutheran, Calvinist, and Anglican branches of the Reformation dramatically reformed this Catholic inheritance. Like Catholics, these various Protestant groups retained the naturalist perspective of marriage as an association created for procreation of children and protection of the couple from sexual sin. They also retained the contractual perspective of marriage as a voluntary association formed by the mutual consent of the couple. Unlike Catholics, however, Protestants rejected the subordination of marriage to celibacy and the celebration of marriage as a sacrament. According to common Protestant lore, the person was too tempted by sinful passion to forgo God's soothing remedy of marriage. The celibate life had no superior virtue and was no prerequisite for ecclesiastical service. It led too easily to concubinage and homosexuality and impeded too often the access and activities of the clerical office. Moreover, marriage was not a sacrament. It was instead an independent social institution ordained by God and equal in dignity and social responsibility with the church, state, and other social estates. Participation in marriage required no prerequisite faith or purity and conferred no sanctifying grace, as did the true sacraments of baptism and the eucharist.

From this common critique, the Lutheran, Calvinist, and Anglican traditions constructed their own models of marriage. Each Protestant tradition provided a different theological formula for integrating the inherited contractual, natural, and spiritual perspectives on marriage. Lutherans emphasized the social dimensions of marriage, Calvinists the covenantal dimensions, Anglicans the commonwealth dimensions. Each Protestant tradition also assigned principal legal responsibility for marriage quite differently. Lutherans consigned legal authority mostly to the state, 
Calvinists to both state and church together, Anglicans mostly to the church subject to state oversight. These differences in emphasis and authority among early Protestants were based, in part, on differences among their theological models of marriage.

Lutheranism. The Lutheran tradition, from 1517 forward, developed a social model of marriage, grounded in Martin Luther's doctrine of the heavenly and earthly kingdoms. ${ }^{3}$ Marriage, Luther and his colleagues taught, was a social estate of the earthly kingdom of creation, not a sacred estate of the heavenly kingdom of redemption. Though divinely ordained, marriage was directed primarily to human ends, to the fulfilling of civil and spiritual uses in the lives of the individual and of society. Marriage revealed to persons their sin and their need for God's marital gift: this was its theological use. Marriage restricted prostitution, promiscuity and other public sexual sins: this was its civil use. Marriage taught love, restraint, and other public virtues: this was its pedagogical use.

Any fit man and woman were free to enter such unions, clerical and lay alike. Indeed, all persons were encouraged to marry when they came of age, unless they had the rare gift of continence. To reject God's gift of marriage was to court the sins of lust and to spurn the blessings of love. Marriage was an especially important calling for the Christian pastor: a pastor's own marital experience could only enhance his pastoral ministry to the married, and his marital parsonage would serve a model for proper Christian living in the community. Marriage was also an important calling for the widow and the widower: this newly single party, who had known the warmth and pleasures of sexual intimacy, would be doubly tempted to sexual $\sin$ in its sudden absence.

As part of the earthly kingdom, Lutheran reformers argued, marriage was subject to the civil law of the state, not to the canon law of the church. To be sure, marriage was still subject to God's law, but this law was now to be administered by Christian magistrates who were God's vice-regents in the earthly kingdom. Church officials were required to counsel the magistrate about God's law and to cooperate with him in publicizing and disciplining marriage. All church members, as part of the priesthood of believers, were required to counsel those who contemplated marriage, to admonish those who sought annulment or divorce, and to aid in the rearing of all children as their collective baptismal vows prescribed. But principal legal authority over marriage and family life lay with the state, not with the church.

\footnotetext{
${ }^{3}$ For general overviews, see Steven Ozment, Ancestors: The Loving Family in Old Europe (Cambridge, MA: Harvard University Press, 2001); Joel F. Harrington, Reordering Marriage and Society in Reformation Germany (Cambridge: Cambridge University Press, 1995); Uwe Sibeth, Eherecht und Staatsbildung: Ehegesetzgebung und Eherechtsprechung in der Landgrafschaft Hessen(-Kassel) in der frühen Neuzeit (Darmstadt: Hessischen Historischen Kommission Darmstadt, 1994); Herman Selderhuis, Marriage and Divorce in the Thought of Martin Bucer, trans. John Vriend and Lyle D. Biersma (Kirksville, MO: Thomas Jefferson University Press, 1999); Hartwig Dieterich, Das protestantische Eherecht in Deutschland bis zur Mitte des 17. Jahrhunderts (Munich: Claudius Verlag, 1970).
} 
This new Lutheran social model of marriage was reflected in the transformation of marriage law in Germany, Scandinavia, and other Lutheran polities of Western Europe. Civil marriage courts replaced church courts. New civil marriage statutes replaced traditional canon law rules. Lutheran jurists published scores of treatises on marriage law, affirming and embellishing the new Lutheran theology of marriage. The new Lutheran marriage law, like the new Lutheran marriage theology, remained indebted to the Catholic canon law tradition. Traditional marriage laws, like prohibitions against unnatural sexual relations and against infringement of basic marital functions, remained in effect. Impediments that protected free consent, that implemented biblical prohibitions against marriage of relatives, and that governed the couple's physical relations were largely retained. Such laws were as consistent with the Catholic sacramental model as with the Lutheran social model of marriage.

But changes in marriage theology also yielded changes in marriage law. Because the Lutheran reformers rejected the subordination of marriage to celibacy, they rejected laws that forbade clerical and monastic marriage, that denied remarriage to those who had married a cleric or monastic, and that permitted vows of chastity to annul promises of marriage. Because they rejected the sacramental nature of marriage, the reformers rejected impediments of crime and heresy and prohibitions against divorce in the modern sense. Marriage was for them the community of the couple in the present, not their sacramental union in the life to come. Where that community was broken, for one of a number of specific reasons, such as adultery, desertion, or habitual abuse of spouse or children, the couple could sue for divorce, leaving at least the innocent party with the right to remarry. Because persons by their lustful nature were in need of God's remedy of marriage, the reformers removed numerous impediments to marriage not countenanced by Scripture. Because of their emphasis on the Godly responsibility of the prince, the pedagogical role of the church and the family, and the priestly calling of all believers, the reformers insisted that both marriage and divorce be public. The validity of marriage promises depended upon parental consent, witnesses, church consecration and registration, and priestly instruction. Couples who wished to divorce had to announce their intentions in the church and community and to petition a civil judge to dissolve the bond.

Calvinism. The Calvinist tradition, established in mid-sixteenth century Geneva, set out a covenantal model of marriage. ${ }^{4}$ This model confirmed many of the Lutheran theological and legal reforms, but cast them in a new ensemble. Marriage, John Calvin and his followers taught, was not a sacramental institution of the church, but a covenantal association of the entire community, modeled on the

\footnotetext{
${ }^{4}$ Robert M. Kingdon, Adultery and Divorce in Calvin's Geneva (Cambridge, Mass./London, 1995); Walter Köhler, Zürcher Ehegericht und Genfer Konsistorium, 2 vols. (Leipzig: Verlag von M. Heinsius Nachfolger, 1942); Cornelia Seeger, Nullité de mariage divorce et séparation de corps a Genève, au temps de Calvin: Fondements doctrinaux, loi et jurisprudence (Lausanne: Méta-Editions, 1989); John Witte, Jr. and Robert M. Kingdon, Sex, Marriage, and Family in John Calvin's Geneva, 2 vols. (Grand Rapids, MI: Wm. B. Eerdmans, 2005-2012).
} 
covenant relationship between Yahweh and ancient Israel. A variety of parties participated in the formation of this covenant. The marital parties themselves swore their betrothals and espousals before each other and God -- rendering all marriages tripartite agreements, with God as third party witness, participant, and judge. The couple's parents, as God's lieutenants for children, gave their consent to the union. Two witnesses, as God's priests to their peers, served as witnesses to the marriage. The minister, holding God's spiritual power of the Word, blessed the couple and admonished them in their spiritual duties during the mandatory church wedding liturgy. The magistrate, holding God's temporal power of the sword, registered the couple and protected them in their person and property after the compulsory state licensing and registration of the marriage. Each of these parties - parents and peers, ministers and magistrates -- was considered essential to the legitimacy of the marriage, for they each represented a different dimension of God's involvement in the covenant. To omit any such party was, in effect, to omit God from the marriage covenant.

The covenant of marriage, as Calvin understood it, was grounded in the order of creation and governed by the law of God. At creation, God ordained the structure of marriage to be a life-long union between a fit man and a fit woman of the age of consent and with the capacity to enter a marital contract with each other. God assigned to this marriage the interlocking purposes of mutual love and support of husband and wife, mutual procreation and nurture of children, and mutual protection of both parties from sexual sin. Thereafter, God set forth in reason, conscience, and the Bible, a whole series of commandments and counsels for proper adherence to this ideal created structure and purpose of marriage.

God's moral law for the covenant of marriage set out two tracks of marital norms, Calvin taught -- civil norms, which are common to all persons, and spiritual norms, which are distinctly Christian. This moral law, in turn, gave rise to two tracks of marital morality -- a simple morality of duty demanded of all persons regardless of their faith, and a higher morality of aspiration demanded of believers in order to reflect their faith. It was the church's responsibility to teach aspirational spiritual norms for marriage and family life. It was the state's responsibility to enforce mandatory civil norms. This division of responsibility was reflected in sixteenthcentury Geneva and later Calvinist polities in the procedural divisions between the church consistory and the city council. In marriage cases, the consistory was the court of first instance, and would call parties to their higher spiritual duties, backing their recommendations with threats of spiritual discipline. If such spiritual counsel and discipline failed, the parties were referred to the city council to compel them, using civil and criminal sanctions, to honor at least their basic civil duties for marriage.

This Calvinist covenantal model mediated both sacramental and contractual understandings of marriage. On the one hand, this covenant model confirmed the sacred and sanctifying qualities of marriage -- without ascribing to it sacramental functions. Marriage was regarded as a holy and loving fellowship, a compelling 
image of the bond between Yahweh and his elect, Christ and his church. But marriage was no sacrament, for it confirmed no divine promise. On the other hand, this covenant model confirmed the contractual and consensual qualities of marriage -- without subjecting it to the personal preferences of the parties. Marriage depended for its validity and utility on the voluntary consent of the parties. But marriage was more than a mere contract, for God was a third party to every marriage covenant, and he set its basic terms in the order and law of creation. Freedom of contract in marriage was thus effectively limited to choosing maturely which party to marry -- with no real choice about the form, forum, or function of marriage once a fit and willing spouse was chosen.

This new Calvinist model of marriage was reflected in a long series of new statutes that Calvin and his colleagues helped to craft for Geneva in the 1540s to 1560 s, and these were emulated in numerous Calvinist communities throughout Europe and later North America. These statutes governed in copious detail marital formation, maintenance, and dissolution, child care, custody, and control, spousal rights, responsibilities, and remedies and more -- often combining Catholic canon law, Lutheran civil law, classical Roman law, and ancient Talmudic law, together with striking legal innovations introduced by Calvin and his colleagues.

Anglicanism. The Anglican tradition of the sixteenth and seventeenth centuries brought forth a commonwealth model of marriage. ${ }^{5}$ This model embraced the sacramental, social, and covenantal models inherited from the Continent but went beyond them. Marriage was at once a gracious symbol of the divine, a social unit of the earthly kingdom, and a solemn covenant with one's spouse. But the essential cause, condition, and calling of the family was that it served and symbolized the common good of the couple, the children, the church, and the state all at once. Marriage was appointed by God as "a little commonwealth" to foster the mutual love, service, and security of husband and wife, parent and child. It was likewise appointed by God as a "seedbed and seminary" of the broader commonwealth to teach church, state, and society alike essential Christian and political norms and habits.

At first, this commonwealth model served to rationalize the traditional hierarchies of husband over wife, parent over child, church over household, state over church. After decades of experimentation, England in the mid-sixteenth century had formally rejected most Protestant legal reforms of marriage introduced on the Continent. It returned to much of the medieval canon law of marriage administered by the church, but now under the supreme headship of the English Crown and the legal direction of Parliament. To call the marital household "a little commonwealth"

${ }^{5}$ Chilton L. Powell, English Domestic Relations 1487-1653: A Study of Matrimony and Family Life in Theory and Practice as Revealed by the Literature, Law, and History of the Period (New York: Columbia University Press, 1917); Eric Josef Carlson, Marriage and the English Reformation (Oxford: Blackwell, 1994); James T. Johnson, A Society Ordained by God: English Puritan Marriage Doctrine in the First Half of the Seventeenth Century (Nashville: Abingdon Press, 1970); Lawrence Stone, The Family, Sex, and Marriage in England, 1500-1800 (New York: Harper \& Row, 1979). 
was to signal its subordinate place within the new hierarchy of social institutions that comprised "the great commonwealth" of England. It was also to call the household to an internal hierarchy of offices that matched the royal and episcopal offices of the great commonwealth - with the paterfamilias' role of ruler within each family serving as a miniature model of the king as the supreme head of the church and commonwealth of England. The commonwealth model was thus used to integrate a whole network of parallel domestic and political duties rooted in the Bible and English tradition. Anglican divines and moralists expounded at great length the reciprocal duties of husband and wife, parent and child, master and servant that would produce a well-ordered little commonwealth. And, in keeping with the tradition of stability of the great political commonwealth of England, these same Anglican writers prohibited the dissolution of this little domestic commonwealth of the family by divorce.

As the political concept of the English commonwealth was revolutionized and democratized in the seventeenth century, however, so was the English commonwealth model of marriage. The traditional hierarchies of husband over wife, parent over child, and church over family were challenged with a revolutionary new principle of equality. The biblical duties of husband and wife and of parent and child were recast as the natural rights of each household member against the other. The traditional idea of a created natural order met with a new idea of marriage, society, and state formed voluntarily by contracts by individuals in the state of nature. Just as the English commonwealth could be rent asunder by force of arms when it abused the people's natural rights, so the family commonwealth could be put asunder by suits at law when one spouse abused the other's marital rights. Just as the King could be beheaded for abuses in the Commonwealth, so the paterfamilias could be removed from the head of the little commonwealth for abuses in the household. This revolutionary construction of the commonwealth model provided the rationale for the incremental liberalization of English marriage law in the course of the next two centuries. It also provided a stepping-stone for the development of a more overtly contractarian model of marriage slowly developed by Enlightenment reformers in the eighteenth and nineteenth centuries.

\section{John Locke's Commonwealth Model and the Road to Modernity}

John Locke's reconstruction of the commonwealth model of marriage in his famous Two Treatises on Government (1690) provides a good example of a transition figure who sought to mediate these traditional Christian models of marriage with the emerging teachings of the Western Enlightenment. ${ }^{6}$ His insights also provide a good example of an early attempt to harmonize liberal and traditional views of marriage.

\footnotetext{
6 John Locke, Two Treatises of Government (1698), ed. Peter Laslett (Cambridge: Cambridge University Press, 1960). The quotes that follow are from ibid., I.9, 47, 98, II.2, 77-86. On Locke's family theory, see sources and discussion in Scott Yenor, Family Politics: The Idea of Marriage in Modern Political Thought (Waco, TX: Baylor University Press, 2011), 19-38.
} 
In his Two Treatises, Locke set out to refute Robert Filmer's monarchical theory of government, which was among the strongest traditional formulations of the Anglican commonwealth model available in the mid-seventeenth century. Filmer had argued that God had created the patriarchal domestic commonwealth headed by the paterfamilias as the source of the hierarchical political commonwealth headed by the King. God had created Adam and Eve as founders not only of the first marriage and family, but also of the first state and society. Adam was the first husband but also the first ruler. Eve was the first wife, but also the first subject. Together with their children, they comprised at once a domestic and a political commonwealth. All persons thereafter were, by birth, subject to the highest male head, descended from Adam.

Locke responded to Filmer first by flatly denying any natural or necessary connection between the political and domestic commonwealths, between the authority of the paterfamilias and the power of the magistrate. "[T]he Power of a Magistrate over a Subject," he wrote, "may be distinguished from that of a Father over his Children, a Master over his Servant, a Husband over his Wife, and a Lord over his Slave." The "little Commonwealth" of the family is "very far from" the great commonwealth in England "in its Constitution, Power and End." "[T]he Master of the Family has a very distinct and differently limited Power, both as to time and extent, over those several Persons that are in it; ... he has no Legislative Power of Life and Death over any of them, and none too but what a Mistress of a Family may have as well as he."

Locke responded next by denying Filmer's patriarchal interpretation of the creation story in Genesis 1:26-28: "Then God said, 'Let us make man in our image, after our likeness.... So God created man in his own image, in the image of God he created him, male and female he created them. And God blessed them, and God said to them, 'Be fruitful and multiply and fill the earth and subdue it...'." God did not create Adam and Eve as ruler and subject, but as husband and wife, said Locke. Adam and Eve were created equal before God. Each had natural rights to use the bounties of Paradise. Each had natural duties to each other and to God. After the fall into sin, God expelled Adam and Eve from the Garden. He increased man's labor in his use of creation. He increased woman's labor in the bearing of children. He said to Eve: "thy desire shall be to thy husband, and he shall rule over thee" (Gen. 3:16). These words, said Locke, which Filmer "calls the Original Grant of Government were not spoken to Adam, neither indeed was there any Grant in them made to Adam; they were a Punishment laid upon Eve." These words do not abrogate the natural equality, rights, and duties with which God created Adam and Eve, and all persons after them. They do not render all wives eternally subject to their husbands. And they certainly do not, as Filmer insists, give "a Father or a

\footnotetext{
${ }^{7}$ Robert Filmer, Patriarcha and other Political Works, ed. Peter Laslett (Oxford: Oxford University Press, 1949); G.J. Schochet, Patriarchalism in Political Thought: The Authoritarian Family and Political Speculation and Attitudes Especially in Seventeenth Century England (New York: Basic Books, 1975).
} 
Prince an Absolute, Arbitrary, Unlimited and Unlimitable Power, over the Lives, Liberties, and Estates, of his Children and Subjects."

Men and women are born free and equal in the state of nature. But "God having made Man such a Creature, that, in his own Judgment, it was not good for him to be alone, put him under strong Obligation of Necessity, Convenience, and Inclination to drive him into Society," Locke argued. A person entered into society by entering into voluntary contracts with other persons of similar inclination. To that extent, the commonwealths of marriage, church, and state might be said to be related, said Locke. Each of these commonwealths was formed by the voluntary agreement of free and equal persons, moving from the state of nature to a social state.

"The first Society" to be formed "was between Man and Wife, which gave beginning to that of Parents and Children." This "conjugal society," like every other society, "is made by a voluntary Compact between Man and Woman: and tho' it consists chiefly in such a Communion and Right in one another's Bodies, as is necessary to its Chief End, Procreation; yet it draws with it mutual Support and Assistance and Communion of Interest too, as necessary not only to unite their Care, and Affection, but also necessary to their common Off-spring, who have a Right to be nourished and maintained by them, till they are able to provide for themselves." Marriage has no necessary form or function beyond this "Chief End" of procreation, Locke argued against traditional understandings. Couples were free to contract about the rest of the relationship as they deemed fit. "Conjugal society might be varied and regulated by that Contract, which unites Man and Wife in that Society, as far as may consist with Procreation and the bringing up of Children till they could shift for themselves; nothing being necessary to any Society, that is not necessary to the ends for which it is made."

Locke thus combined a contractual and naturalist perspective on marriage. It was a natural right for a man and woman to enter into a marital contract. It was a natural duty for them to render procreation an essential condition of their marital contract. It was the natural right to survival of their child that imposed on parents a further natural duty to remain in their marriage once contracted till their children were self-sufficient. "For the end of conjunction between Male and Female, being not barely Procreation, but the continuation of the Species, this conjunction betwixt Male and Female ought to last, even after Procreation, so long as is necessary to the nourishment and support of the young Ones, who are to be sustained by those that got them, till they are able to shift and provide for themselves.... whereby the Father, who is bound to take care for those he hath begot, is under an Obligation to continue in Conjugal Society with the same Woman longer than other Creatures, whose young being able to subsist of themselves, before the time of procreation returns again, the Conjugal Bond dissolves of it self, and they are at liberty...."

The logical end of Locke's argument was that the childless couple, or the couple whose children were of age, should be free to divorce, unless they had found 
some other "Communion of Interest" to sustain their contract. Locke dithered on the question of divorce. It was not essential to his political argument to speak definitively on the subject, and he knew the dangers of loose literary speculation on it in England in his day. In his private diary, he wrote quite brashly: "He that already is married may marry another woman with his left hand. . . The ties, duration, and conditions of the left hand marriage shall be no other than what is expressed in the contract of marriage between the parties." ${ }^{8}$ In his Two Treatises and other publications, he only flirted with the doctrine of divorce and remarriage, suggesting delicately that the matter be left to private contractual calculation: "[T]he husband and wife, though they have but one common Concern, yet having different understandings will unavoidably sometimes have different wills too; it therefore being necessary, that the last Determination, i.e., the Rule, should be placed somewhere, it naturally falls to the Man's share, as the abler and the stronger. But the reaching but to the things of their Common Interest and Property, leave the Wife in the full and free possession of what by Contract is hers by peculiar Right, and gives the Husband no more power over her Life, than she has over his. The Power of the Husband being so far from that of an absolute Monarch, that the Wife has, in many cases, a Liberty to separate from him; where natural Right, or their Contract allows it, whether that Contract be made by themselves in the state of Nature, or by the Customs or Laws of the Countrey they live in; and the Children upon such Separation fall to the Father's or the Mother's Lot, as such Contract does determine."

The other logical end of this argument was that the state had little role to play within marriage and the family. For the state likewise was a voluntary assembly, formed by a governmental contract among like-minded parties. The state was formed after marriage and the family, and was ultimately subordinate to it in priority and right. The marriage contract sets the terms of the agreement between husband and wife, parent and child. The state could intervene only to enforce these contractual rights and duties, and only to vindicate the natural rights and duties of each party within the household. "For all the ends of Marriage being to be obtained under Politick Government, as well as in the state of Nature, the Civil Magistrate doth not abridge this Right, or Power of either naturally necessary to those ends, viz., Procreation and mutual Support and Assistance whilst they are together; but only decides any Controversie that may arise between Man and Wife about them."

Locke did not press this contractarian reconstruction of the commonwealth model to the revolutionary ends that some Enlightenment writers would reach in the following centuries. Locke was a man of pious Anglo-Puritan stock who remained firmly devoted to biblical teachings throughout his life. What he gave with his political hand, he took back with his theological hand. His famous Letters on Toleration and The Reasonableness of Christianity were tracts of deep Christian conviction. In each of them, Locke called church and state to end their unhealthy alliance, to soften their belligerent dogmatism, to return to the simple moral truths of the New Testament. In each of these tracts, he also insisted on coating his doctrine

${ }^{8}$ Diary Entry, 1678, 1679, quoted in editor's note to ibid., II, 81, in Laslett, ed., Two Treatises (paperback ed.), 364 
of natural rights and duties with a number of classic Christian conceptions about the natural propriety of heterosexuality, monogamy, procreation, nurture and education of children, and the like. "[H]e that shall collect all the moral rules of the philosophers and compare them with those contained in the New Testament," he wrote, "will find them to come short of the morality delivered by our Saviour, and taught by his apostles.... Such a law of morality Jesus Christ hath given us in the New Testament [is] a full and sufficient rule for our direction, and conformable to that of reason." ${ }^{9}$

On the strength of these convictions, Locke endorsed a whole series of biblical teachings on marriage and sex that stood in considerable tension with his more radical statements on marriage in the Two Treatises. For example, Locke endorsed Christ's reading of the Commandment against adultery as an injunction not only against "actual uncleanness, but all irregular desires [and] causeless divorces." He endorsed St. Paul's injunctions against fornication, saying that such conduct "might be so unsuitable to the state of a christian man, that a christian society might have reason to animaadvert upon a fornicator ... as not comporting with the dignity and principles of that religion, which was the foundation of their society." He glossed St. Paul's teachings in I Corinthians 7 on the relative merits of marriage and celibacy with a matter-of-fact tone that reflects comfortable acceptance of traditional Christian doctrine. Glossing St. Paul's statements on the rights and duties of husbands and wives, Locke wrote: "The woman (who in all other rights is inferiour) has here the same power given her over the man's body, that the man has over her's. The reason whereof is plain; because if she had not her man, when she had need of him, as well as the man his woman, when he had need of her, marriage would be no remedy against fornication." He paraphrased, without comment, Paul's requirement that husband and wife remain together till parted by death. He glossed Paul's later requirements that wives must submit to their husbands, and husbands to love their wives thus: "It is from the head that the body receives its vigorous constitution of health and life; this St. Paul pronounces here of Christ, as head of the church, that by that parallel which he makes use of, to represent the relation of husband and wife, he may both show the wife the reasonableness of her subjection to her husband, and the duty incumbent on the husband to cherish and preserve his wife...."10

Locke stretched the commonwealth model of marriage -- and indeed all prior Christian models of marriage -- to the breaking point. On the one hand, he was a devout Christian, fully conversant with biblical teachings on marriage and sexuality, but not fully comfortable with their theological exposition or legal implementation in his day. On the other hand, he was a devoted libertarian, fully supportive of the

9 John Locke, The Reasonableness of Christianity, in The Works of John Locke, 12th ed. (London: C. \& J. Rivington et al., 1824), 6:140-143. See also ibid., 11-15, and the fuller account in his Essay on the Law of Nature, W. von Leyden, trans. and ed. (Oxford: Oxford University Press, 1954).

${ }^{10}$ See, Locke, Reasonableness of Christianity, 115; id., A Paraphrase and Notes on St. Paul's First Epistle to the Corinthians, in Locke, Works, 7:118-23 (notes on I Cor. 6:12, 7:1-4); id., A Paraphrase and Notes on St. Paul's Epistle to the Ephesians, in Locke, Works, 7:488 (notes on Eph. 5:23). 
revolutionary reconstruction of the English commonwealth, but not fully satisfied with its philosophical foundation or its legal reification during the Glorious Revolution. From both perspectives, he pressed for a variety of reforms of marriage, family, and sexuality - even while retaining much of the traditional understanding of marriage as heterosexual monogamous union presumptively for life designed for the mutual protection, pleasure, and procreation of husband and wife.

Locke the theologian and Locke the political philosopher agreed on many points of marital reform -- greater freedom of marital contract, greater equality of husband and wife, greater emphasis on the procreation and education of children, greater restraint on the separation of couples with children, greater protection of wives, children, and servants from abuse. On this twin theological and philosophical foundation, Locke helped to prepare the way for many of the legal reforms in the common law of England and the broader English Commonwealth over the next three centuries. His views on marriage had no immediate legal impact, but they proved remarkably prescient and prophetic.

Locke the theologian and Locke the political philosopher, however, parted ways on many points as well. Locke the theologian emphasized the biblical norm of marriage as a hierarchical order headed by the husband with subjection by the wife. Locke the philosopher emphasized the voluntary organization of marriage as a negotiated contract between two equal parties. Locke the theologian vested both church and state with a prominent role in the policing of marital and sexual conduct. Locke the philosopher countenanced no role for the church, and a minimalist role for the state in policing the conduct of the household. Locke the theologian emphasized the duties of marital love, spiritual companionship, and sexual fidelity for life. Locke the philosopher emphasized the rights of marital equality, procreative capacity, and parental fidelity until children came of age.

Many skeptical readers of his day dismissed Locke as an intellectual schizophrenic, a man incapable of harmonizing his theological convictions and political speculations on marriage, and thus prone to intemperate remarks and indecisive principles on both scores. More sympathetic readers hailed Locke as a methodological genius, a man who liberated the theology and politics of marriage from each other. By distinguishing a natural versus biblical, and a political versus theological discourse on marriage, Locke broke the presumed organic connections between the domestic commonwealth and the political commonwealth, household and state, father and king, child and subject. The household could have its own order and organization based on the marital contract; the state could have its own offices and functions based on the social contract. The church could have its norms for marriage based on biblical revelation; the state could have its norms for marriage based on natural rights. The church could ground its norms of authority and obedience in the Fifth Commandment ("Honor your father and mother"); the state could ground its norms for authority and obedience in the social contract. A pious Christian could accept the literal truths of the Bible for his private life, yet advocate the liberal reforms of the social contract for public law. 
To accept Locke's method was to accept the proposition that it was no longer necessary to integrate the spiritual, natural, social, and contractual perspectives on marriage in an organic model -- whether the Anglican commonwealth model or any of the other sacramental, social, or covenantal models of the tradition. With Locke's method, natural and contractual perspectives on marriage could be fully expounded without reference to their religious and social implications. Religious and social perspectives on marriage could be fully defended without reference to their natural or contractual dimensions. Moreover, it was no longer necessary for state, church, or civil society to play an integrated role in the governance of marriage. Marriage was the first society a person entered from the state of nature, and the terms of the marital contract together with the person's natural rights and duties were superior to all other governing norms. If the married person chose to enter into a political, or an ecclesiastical, or a civic society, he or she could subscribe to the marital norms of that particular society. But these sets of norms were independent of each other, and subordinate to the natural and contractual norms of the marital contract.

Hugo Grotius, the seventeenth-century Dutch political philosopher on whom Locke partly relied for his philosophical constructions, once ventured the impious hypothesis that the law of nature could be valid even if "we should concede that which cannot be conceded without the utmost wickedness, that there is no God, or that the affairs of men are of no concern to him." ${ }^{11}$ This idea was hardly original with Grotius, and hardly acceptable to the establishment of his day. But Grotius's articulation of it in the midst of the bitter religious warfare and persecution of early seventeenth-century Europe proved propitious. It helped to set afoot the development of a law of nations and a law of the sea that did not depend upon a common theological foundation or necessary role for the Christian church.

A similar claim might be made about Locke's "impious hypothesis" that a law of marriage could be valid even if God were not acknowledged as the founder of the marriage contract, or the church not accepted as an agent in the governance of marriage. This idea, too, was hardly original with Locke, and hardly acceptable to the establishment of his day. But Locke's articulation of an independent naturalist and contractarian theory of marriage in the midst of the revolutionary upheaval of English society also proved propitious. It helped to set afoot the development of an Anglo-American theory and law of marriage and the family that eventually no longer depended upon established theological doctrines or upon a necessary legal role for the church - though it left open voluntary religious and ecclesiastical forms and forums of marriage.

Locke's early insights live on in the common law traditions of separating church and state in the governance of sex, marriage, and family life. In most common law lands today, it is the state that defines the norms of marriage, family, and sexuality that are permissible in the community, even though these state's norms often depart radically from prevailing religious teachings. Also in most common law nations today, religious officials still may officiate at weddings and

${ }^{11}$ Hugo Grotius, De Jure Belli ac Pacis (1625), Prolegomena, 11. 
declare a couple married "by the power of the state vested" in them. These religious officials also still have freedom to add steps to the state's marital formation requirements (such as premarital counseling) and to refuse to marry same-sex or interreligious couples, or those whose moral lives are not consonant with the religious community's teaching.

Common law lands, however, now face growing pressure for a stronger separation of religion and state in the formation and governance of marriage. One manifestation of this separationist pressure is the agitation to end the traditional practice of giving religious officials the power to declare a marriage on behalf of the state. That reform, which has support among selected clergy and political officials, would entirely separate the religious consecration of marriage from its legal formation, giving the state a monopoly over marriage law. It would also relieve the growing pressure on religious communities to consecrate every form of marriage recognized by the state, even those forms directly contrary to the religious communities' teaching.

A second, opposite manifestation of this separationist pressure is the agitation for religious communities to have their own religious laws governing marriage which their voluntary faithful have freedom to adopt in lieu of state law. That reform, which has its strongest support among some minority religions in the West, especially Jews and Muslims, would leave the choice of what marriage law governs entirely in the hands of the married couple. ${ }^{12}$ The argument to provide citizens with a straight choice between state and religious marriage laws is now pressed in part on the Lockean terms which we discussed above. One of Locke's most basic teachings is that marriage is a pre-political and pre-legal institution. It comes before the state and its positive laws, both in historical development and in ontological priority. As we saw, Locke regarded the marital contract as "the first contract" and "the first society" to be formed as men and women came forth from the state of nature. The broader social contract came later, presupposing stable marital contracts. And contracts to form state governments, churches, and other voluntary associations within this broader society came later still. Why, on this simple contractarian logic, modern reformers now argue, should the state get exclusive jurisdiction over marriage? After all, it was sixteenth-century Protestants, not eighteenth-century Enlightenment philosophers who first vested the state with marital jurisdiction. But why is state jurisdiction over marriage mandatory, or even necessary? Before the sixteenth-century Protestant Reformation -- and in many Catholic lands well after the Reformation, too -- the Catholic canon law and Catholic church courts governed marriage. Moreover, even in Protestant England until the nineteenth century, the state delegated to ecclesiastical courts the power to treat many marriage and family questions. There is evidently nothing inherent in the structure of Western marriage and family law that requires that it be administered by the state. And there is nothing ineluctable in liberalism's contractarian logic that

\footnotetext{
${ }^{12}$ See the range of perspectives in Joel A. Nichols, ed., Marriage and Divorce in a Multicultural Context: Multitiered Marriage and the Boundaries of Civil Law and Religion (Cambridge: Cambridge University Press, 2011).
} 
requires marital couples to choose the state rather than their own families or their own religious communities to govern their domestic lives -- particularly when the state's liberal rules diverge so widely from their own beliefs and practices. On this latter argument, conservative Muslims sometimes join hands with selected conservative Christians and critical liberals who call for exemption from, or the abolition of, state marriage law - conservative Christians because the state has betrayed traditional Christian teachings on marriage, critical liberals because the state is encroaching on individual privacy and sexual autonomy. ${ }^{13}$

It is hard to predict where these reformist movements might lead. But it is quite clear that Western democracies today are facing as radical a transformation of sex, marriage, and family law as anything that obtained in the Protestant Reformation. In the midst of such tumult, it is wise to revisit these great battles of the sixteenth century to see what was at stake, to see why they constructed what they did, and to see whether those earlier reformers still have something valuable to teach us, even in these post-modern and post-Christian times.

\footnotetext{
${ }^{13}$ See sources and discussion in John Witte, Jr., "The Future of Muslim Family Laws in Western Democracies," Sharia in the West, ed. Rex Ahdar and Nicholas Aroney (Oxford: Oxford University Press, 2011), 279-292.
} 